o qual foi analisado e classificado como transudato hemorrágico. Foi prescrito furosemida e enalapril, mas o animal veio a óbito no dia seguinte. A necrópia observou-se massa em átrio direito, carcaterizada como hemangiossarcoma cavernoso pelo exame histopatológico. Os cães com neoplasia cardiaca podem apresentar sintomatologia variada, a depender da localização, tamanho e infiltração do tumor. A confirmação do diagnóstico é realizada, freqüentemente, pela necrópsia e o prognóstico é ruim devido às limitações no tratamento.

\title{
79 - Análise retrospectiva do Tumor Venéreo Transmissível (TVT) em cadelas, durante os anos de 1996 a 2002. Avaliação da resposta ao tratamento quimioterápico
}

Bueno, M.G. '; Brito, C.P. ${ }^{2}$; Haipek, K. '; Oliveira, C.M. ${ }^{3}$
1-Médica Veterinária estagiária do Serviço de Obstetrícia e Ginecologia do Hospital Veterinário da Faculdade de Medicina Veterinária e Zootecnia da Universidade de São Paulo, São Paulo-SP

2 - Pós-Graduanda do Departamento de Reprodução Animal da Faculdade de Medicina Veterinária e Zootecnia da Universidade de São Paulo, São Paulo-SP

3 - Professora Doutora do Departamento de Reprodução Animal da Faculdade de Medicina Veterinária e Zootecnia da Universidade de São Paulo, São Paulo-SP

O tumor venéreo transmissível (TVT) é uma neoplasia de células redondas de origem mesenquimal e é um dos tumores que mais acomete a espécie canina. Geralmente afeta a genitália externa e é usualmente transmitido pelo coito. Outros sítios de ocorrência incluem: cavidade nasal, oral $\mathrm{e}$ tecido subcutâneo. A transmissão é feita entre a célula viável $\mathrm{e}$ a mucosa vaginal ou peniana lesada. A etiologia viral tem sido investigada mas ainda não foi verificada. O TVT tem distribuiçào mundial, mas predomina principalmente em paises de climas tropical e subtropical. Nào existe predisposição racial ou sexual para o TVT de ocorrência natural, porém, parece ser mais comum em animais jovens, errantes e sexualmente ativos. O diagnóstico definitivo é feito por exame histopatológico ou avaliação citológica do tumor. O TVT responde a muitas formas de terapia, tais como cirurgia e radioterapia, porém o tratamento mais efetivo e eficaz ainda é a quimioterapia. O prognóstico é bom, exceto nos animais que apresentam resistência ao tratamento, tendo que ser submetidos à excisão cirúrgica. Desta forma, foi realizado um estudo retrospectivo, que teve como objetivo obter informaçòes relativas às fêmeas caninas portadoras de TVT encaminhadas para tratamento ao Serviço de Ginecologia e Obstetricia do HOVET - USP durante os anos de 1996 a 2002, assim como avaliar a ocorrência de resistência ao tratamento quimioterápico (Sulfato de Vincristina). O total de animais com TVT atendidos durante os 6 anos foi 341. Destes, $134(39 \%)$ responderam satisfatoriamente ao tratamento quimioterápico e foram considerados curados; $189(55 \%)$ não foram tratados por opção do proprietário ou o tratamento foi interrompido e $18(6 \%)$ mostraram resistência durante o tratamento e a resolução do quadro foi cirúrgica. Do total de animais curados, 34 (17\%) responderam com 2 a 3 aplicaçōes do medicamento, 59 (44\%), com 4 a 5 aplicaçōes, $37(27 \%)$ com 6 a 7 doses do quimioterápico e em $14(12 \%)$ foi necessária mais de 7 aplicações da droga para regressão do tumor. Nos animais que desenvolveram resistência 18 (95\%) deixaram de responder ao tratamento à partir da $6^{\mathrm{a}}$ aplicação. Foram anlisados $114(34 \%)$ animais com raça definida e $227(66 \%)$ sem raça definida. Além disso, $69(20 \%)$ animais pertenciam a faixa etária de 0 a 2 anos, $129(37 \%)$ de 3 a $5,85(24 \%)$ de 6 a 8 e $58(19 \%)$ maior que 8 anos. Concluiu-se que nos animais com TVT a maior porcentagem de cura foi obtida com 4 a 5 doses do Sulfato de Vincristina e nos animais que desenvolveram resistência ao medicamento foi necessário associar o tratamento cirúrgico para que houvesse resoluçào do quadro. A maioria dos animais pertenciam ao grupo dos animais sem raça definida e na faixa etária entre 3 a 5 anos. 